\title{
Study and Analysis of Delays in the Material Procurement Process: A case study of Steel Manufacturing Companies at Indonesia
}

\author{
Muhammad Zuhdi Prasetyo Nugroho ${ }^{1}$, Mochamad Eko Nugroho ${ }^{2}$, Marcely Susanti ${ }^{3}$ \\ ${ }^{1-3}$ Master of Industrial Engineering Student \\ Mercu Buana University, Jakarta
}

Indonesia

\begin{abstract}
The procurement of goods is an important activity in maintaining the company's survival, especially in the manufacturing industry. Delay in the acquisition of goods may cause interruption to plant operations. This study aims to find out and analyze the cause of delay in the procurement of goods. The type of investigation used is qualitative descriptive with the subject of inquiry is the person who is directly related to the process of acquiring goods at Steel Manufacturing Companies, which is the employee in the Procurement Division. The results indicate that the main cause of the postponement problems in the procurement of goods is because the process does not use the e-procurement system in the purchase process with a percentage of the cause of a $22 \%$ delay. For the manager as decision-makers need to take on the basis of improvement such as improving the level of cooperation with consumers.
\end{abstract}

Keywords: Coorperation, Delay, Procurement.

\section{INTRODUCTION}

Procurement is an important activity in maintaining the company's survival, especially in the manufacturing industry. Acquisition is the process of getting goods and services at the best expense, in the right quality and quantity, the right time and in the right place to generate profit or direct use for the company [1-2]. In obtaining a factory goods, especially the Procurement Division of Goods requires suppliers or vendors as suppliers of goods and services, which are not only imported from within the country but also from abroad. One way to get a supplier of goods and services is to conduct an open tender by displaying the announcement on Factory's official website. The procurement function of goods and services must be aligned and support the company's strategy. For example, when a company is pursuing a cost reduction strategy, the revenue function must innovate so that the lowest cost of goods and services from third parties is earned. Procurement division has several processes in obtaining barag. The process is indirectly a step to ensure the smoothness of the plant. This process includes, PO (Purchase Order) and Monitoring Process. The PO Monitoring process aims to monitor the procurement process of goods ranging from the PR release process (Purchase Request) to the expenditure of POs (Purchase Order) ordered on time. The timelines are directly related to the main timing or duration of the procurement process, where the main time is a matter that requires special attention in carrying out the various processes carried out in the Procurement Goods Division. The success of this process is one of the key moments.

Analysis needs to be done to identify the causes that affect these delays because the revenue department is required to create excellence in terms of turnover departments can be done by selecting providers who have the ability to deliver shorter goods and time without sacrificing quality and price increases. The speed and timeliness of delivery from suppliers not only allows companies to produce and deliver products to customers on time,

Based on this background, problems and research are formulated, including:

1. What causes delay in getting goods?

2. What effects can be caused by delays in procurement of goods?

3. What is the solution to the delay in obtaining goods? 
The procurement of goods at the agency or company is a routine routine. The acquisition of goods is intended to meet the needs of the goods required for the operation of the company in progress. The process of obtaining goods most commonly done by the company is usually conventional, starting from the procurement process to the report.

The term Lead Time is commonly used in the manufacturing industry, which means that it is the time it takes for a company to fulfill the order or the amount of time that arises between when the process starts and when it is completed. Lead Time relates to company management, where companies want to reduce the amount of time needed to produce good jobs. In business, minimizing advance time is usually more focused. Key management time is the process to ensure that real lead times are targeted. Effective time management has several benefits. This allows the company to use labor and machinery efficiently and help control the expectations or companies.

\section{LITERATURE REVIEW}

\subsection{FishBone Diagram}

Fishbone diagram is an illustration that is used to explore potential or real causes of quality problem. Ishikawa append that Fishbone diagram is to organize and display the intterelationship of various theories of root causes of problem [11], Fishbone diagram if just a group of causes and effect diagrammed to show the interrelationship. The function of fishbone diagrams is to identify and organize causes that arise from specific effects and then separate the root causes. The other function of the diagram is helping to find the root cause of the problem with user friendly [11].Fishbone Diagram devided problem from cause and effect which consist of several factors : First is Machine, Second is Management, third isMaterial, Fourth is manpower, Fifth is Environment,Sixth is Method [5].

This figure will show the effect or outcome of the problem, for a variety of reasons. The effect or impression is written as a snout while the fish bone is filled with reasons according to the problem approach. The cause and effect diagram (cause and effect) because the diagram shows the relationship between cause and effect. According to the statistical process control, a causal diagram is used to indicate the causal factors and the effects (effects) caused by causal factors.

The cause and effect diagram is a diagram that shows the relationship between cause and effect, This causal diagram is often referred to as a Fishbone diagram because of its shape like a fish skeleton, or Ishikawa diagram (Ishikawa diagram) because it was first introduced by Prof. Kaour Ishikawiri from the University of Tokyo 1953 [4].

Basically a causal diagram can be used for the following needs [4]:

- Helps identify the root cause of a problem

- Helps generate ideas for solutions to a problem

- Assist in further investigation or fact finding

\subsection{Pareto Diagram}

Pareto diagram is a rod-shaped graph that illustrates the frequency distribution of attribute data arranged by category, in other words this pareto diagram describes the type of product defect based on the number of events [13]. Pareto Chart is used to identify vital problems by applying a comparison rule of 80:20, which means 80 percent of the increase can be achieved by completing $20 \%$ of the most important problems faced [12].

Pareto diagrams are used to identify and evaluate types / types that are not appropriate. The Pareto Chart was developed by an Italian economist named Vilredo Pareto in the 19th century.

Pareto diagram is a bar graph that shows the problem based on the order of the number of events. The most common problems are indicated by the first bar chart highest and placed on the far left side, and so on until the least problem occurs is indicated by the lowest last bar graph and placed on the far right side. This arrangement will help to determine the importance or priority of the categories of events or causes of the event under study. With the help of Pareto, the diagram will be more effective by focusing on

causes that have the greatest impact on the event rather than reviewing various causes.

Various Pareto Charts can be described using the same data, but are depicted differently. By way of showing data according to the frequency of occurrence, according to cost, according to the time of occurrence, various priority priorities can be expressed depending on the specific needs that exist. As such, it cannot simply be determined that the biggest bar in Pareto Chart is the biggest problem. In this case sufficient information must be collected in advance [4]. 


\section{METHODOLOGY}

The framework of this study is illustrated In Figure 1, which is in two parts :

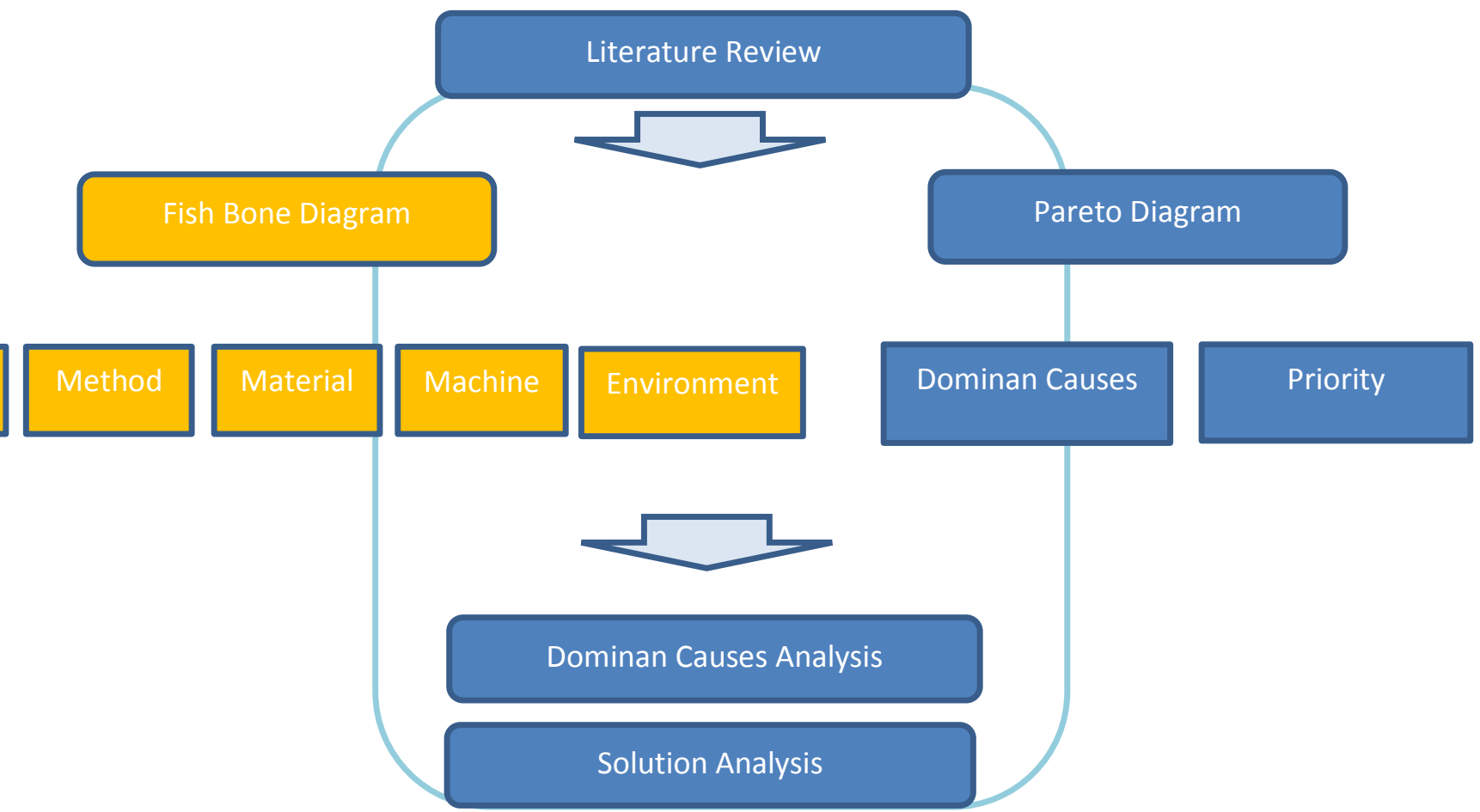

Figure 1: Study Framework (Source: Adopted by research)

This study was conducted using a qualitative descriptive method, as it describes and describes in detail how the procurement process of goods occurs in Manufacturing factory engaged in steel so that factors can be identified which affect the delay in procurement of goods. Data or information is in the form of continuous symptom, and has a standard in using data permissions in an ideal or normal state. This study finds the truth in the form of acceptable generalizations with the human mind, especially the researchers themselves. As for data processing and presentation, researchers use data validity in ideal or normal conditions. This study finds the truth in the form of acceptable generalizations with the human mind, especially the researchers themselves. While processing and delivering data, researchers use qualitative research [9].

Researchers try to explain, describe and interpret how procurement processes carried out by PT. ABC so that factors affecting the procurement process of goods are known. This research attempts to provide explanations and explanations on the procurement process.

\subsection{Informant (Research Subject)}

It is called the subject of research, not the object, because the informant is considered to be actively building the reality, not just the thing that just fill the questionnaire". The number of informers in qualitative research can be easily changed (increased or decreased), depending on availability of data in the field and if no new information is found (bored data) [3].

The number of informants and individuals who become informants has been selected according to the objectives and requirements of the research [3]. The person who can be used as a whistleblower is a person who has experience in line with research, a person who has a certain role in one section and of course easily accessible. Therefore, the subjects in this study are those who are directly related to the acquisition process at Steel Manufacturing Companies, ie person or employee in the Procurement Division of the Goods. In line with the problem limits in this study, research subjects are speeding workers at the Procurement Department at Manufacturing factory engaged in steel which aims to find out what factors can affect the delay in procurement of goods by assisted by Ishikawa diagram or Bone Fish diagram. 


\subsection{Data Collection Method}

According to [8], the understanding of data collection methods is "The technique or method that researchers can use to collect data. There are several data collection techniques or methods that are usually conducted by researchers. problem in hand ". Data collection techniques used in this study include:

A. Library Research

That is, by collecting existing data on the problems in this study by reading relevant literature to support, such as books, journals and the internet on matters that may affect the procurement process.

B. Field research

\subsubsection{Depth Interview}

According to Burhan Bungin [3], regarding in-depth interviews, namely: "In-depth interviews in general are the process of obtaining information for the purpose of inquiry through questioning and face-to-face questions between the interviewer and the informant or interviewee, with or without the guidance interviews, where interviewers and informants engage in relatively long social life, so the rarity of in-depth interviews is their involvement in the life of informers. "

Interviews in this study were conducted for people or workers working in the process of speeding up, beginning with the Procurement Department manager, speeding up division chiefs to expedite division personnel. The process of accelerating is the process of monitoring the journey of goods from the approved purchase plan until the goods are directed to the promised place and time.

\subsubsection{Observation}

In this study, researchers are involved with the daily activities of the people observed or used as sources of research data or commonly called participatory observations. According to [9], observations made by researchers at the Procurement Division of Goods at Steel Manufacturing Companies is a simple participation observation. Simple participation (simple participation):

"means that the researcher maintains a balance between being insider and being outsider".

In this observation there is a balance between researchers as insiders and outsiders. The researchers in collecting this data involve participatory observation in some activities, but not all.

\subsubsection{Documents}

In this study Procurement of Goods Dividers researchers use more documents in the form of writing, such as manuals for procurement procedures.

\section{RESULTS}

The acquisition process at PT.ABC starts from the Request for Purchase (PR) then the tender is made until the bid is entered and negotiated with the tender winner, until the Purchase Order is issued.

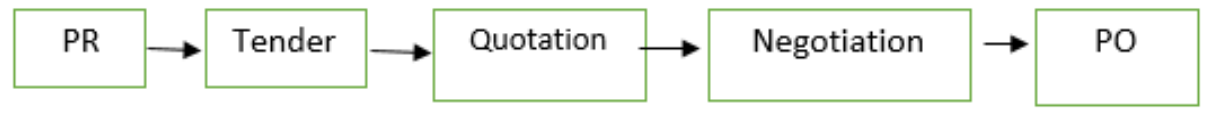

Figure 2: Procurement Process Flow (Source: Adopted by research)

In this study, the data derived from the purchase of goods and the time required to complete the acquisition from September to October 2018, data is taken from the SAP System which is the application of the procurement system used in the company. The following data is available at Steel Manufacturing Companies from September to October 2018.

Table 1. Procurement Lead Time (Source: Adopted by research)

\begin{tabular}{|l|l|c|}
\hline No & Lead Time (Days) & PR Quantity \\
\hline 1 & $1-30$ & 20 \\
\hline 2 & $30-40$ & 20 \\
\hline 3 & $40-60$ & 40 \\
\hline 4 & $60-90$ & 10 \\
\hline 5 & $9>90$ & 10 \\
\hline
\end{tabular}




\begin{tabular}{|l|c|}
\hline TOTAL & 100 \\
\hline
\end{tabular}

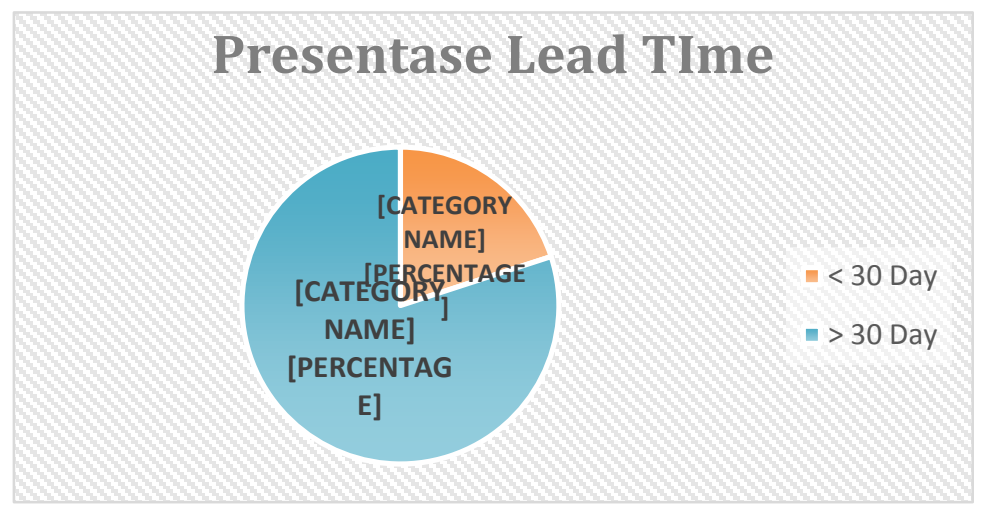

Figure 3: Percentage of Lead Time (Source: Adopted by research)

From the data table above, it is found that the procurement process of more than 30 days is $80 \%$, indicating that the procurement process at Steel Manufacturing Companies is ineffective and efficient so solutions need to be met so that the procurement process can be effective and efficient because the long acquisition process can block the production process of Steel Manufacturing Companies, as it is in accordance with the Steel Manufacturing Companies that the lead acquisition lead time is 30 days after the release of the Purchase Request (PR), because if the acquisition time exceeds the set limit, it will interfere with the production process.

After the source was found, the researcher asked all the Procurement Division employees, amounting to 25 people, to choose which caused them to think the most dominant or frequent and the following were their opinions, namely:

Table 2: Causes of delay (Source: Adopted by research)

\begin{tabular}{|c|l|c|}
\hline No & \multicolumn{1}{|c|}{ Causes Of Delay } & Total \\
\hline 1 & Haven't used e-procurement & 20 \\
\hline 2 & $\begin{array}{l}\text { The amount of manpower is } \\
\text { lacking }\end{array}$ & 15 \\
\hline 3 & $\begin{array}{l}\text { The negotiation and input process } \\
\text { is still manua }\end{array}$ & 9 \\
\hline 4 & Working hours are not effective & 9 \\
\hline 5 & $\begin{array}{l}\text { Supplier Cancel Orders } \\
\text { Unilaterally secara sepihak }\end{array}$ & 9 \\
\hline 6 & $\begin{array}{l}\text { The clarification process is very } \\
\text { long }\end{array}$ & 7 \\
\hline 7 & Material is absolute & 6 \\
\hline 8 & $\begin{array}{l}\text { Material with certain } \\
\text { manufacturers are hard to find }\end{array}$ & $\begin{array}{l}\text { Many files have to be printed } \\
\text { while the printer is slow }\end{array}$ \\
\hline 10 & $\begin{array}{l}\text { Indequate Software Procurement } \\
\text { System }\end{array}$ & 89 \\
\hline & \multicolumn{2}{|c|}{ TOTAL }
\end{tabular}

Of the 25 employees of the Procurement Division who sought their opinion on the factors that most often lead to delays in procurement, mentioning an average of more than one factor. The table above shows that there are 2 dominant factors that occur according to employees ie not using e-procurement with a total of 20 opinions, then suppliers cancel unilateral orders with a total of 15 opinions. 
Therefore, the factors that did not use e-procurement were chosen because of the procurement process at PT. ABC still uses manuals with many face-to-face with vendors and still prints a lot of files, this does cause Karen's inefficient procurement system in many other companies that use the e-procurement system.

Based on the above data, it can be explained that the highest suspension issue in the acquisition of goods is $22 \%$ of all problems arising from the procurement process of goods that have not yet been used for e-procurement system. The principle of Pareto

diagrams is $80 \%$ of the problems that come from $20 \%$ of the reason, so if you can solve $20 \%$ of the problem you can solve $80 \%$ of the problem. In this pareto diagram the problem of postponement in the acquisition of goods can be seen from the highest order to the left to the lowest to the right of the frequency, the purpose of placing the delay problem in acquiring these items is to facilitate decision making.

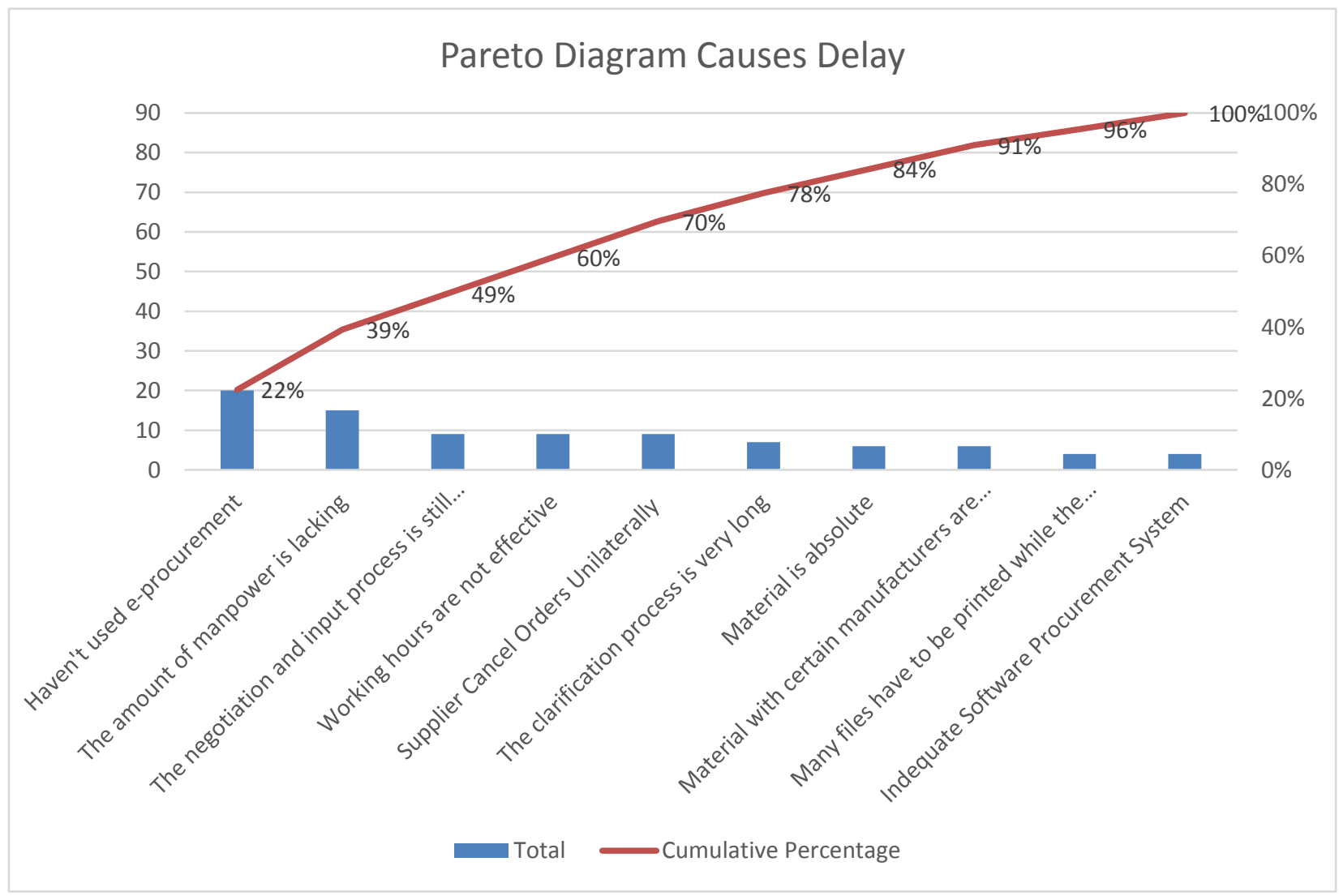

Figure 4: Pareto Diagram (Source: Adopted by research)

In case of delays in procurement of goods, the most common cause is the acquisition system does not use e-procurement. Therefore, accelerating or part-time managers need to take action or corrective action such as by applying the e-procurement system as a procurement system. First of all to a company that has been using the e-procurement system. After knowing the causes of delays that need to be fixed first, here is a pareto diagrams. Although based on Pareto's principle, only $20 \%$ of which cause problems that can cause $80 \%$ of the problem, it does not rule out the possibility to speed up the manager or head of department to look at other reasons, such as the second most frequent factor, that is less labor, because it loads a lot of work. After knowing the reasons for being dominant by the employee, the researcher can make pareto diagrams to find out why the suspension needs to be corrected first.

From the above pareto diagram obtained from employee surveys related to the work, it can be seen that the biggest cause that causes delays is haven't used e-procurement where the percentage is more than $20 \%$, so the main factor that must be corrected is that factor, because the cause of up to $20 \%$ of problems in the Pareto diagram if resolved can solve the problem up to $80 \%$. 


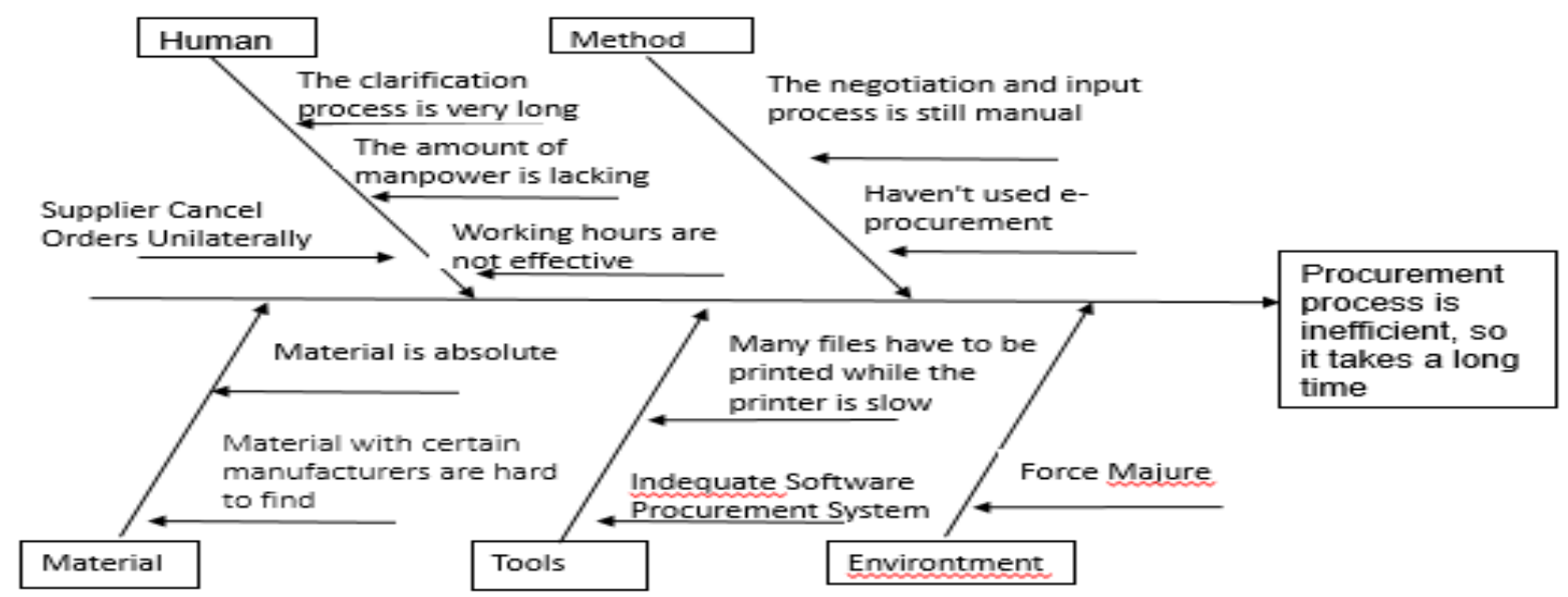

Figure 5: Fishbone diagram (Source: Adopted by research)

An analysis of the reasons for deferment is assisted by using the Ishikawa diagram / fish bone diagrams, where this method will show the effects or consequences of the problem for various reasons. The effect or impression is written as a snout while the fish bone is filled with reasons according to the problem approach. In classifying the reasons for the suspension, researchers use one of the categories in the Ishikawa diagram method.

Ishikawa diagram about the cause of delays in the acquisition of goods detected from the results of this interview is Ishikawa diagram consisting of 4 categories, namely human, methods, materials, tools. The reasons included in the Ishikawa diagram are many factors being said or the factors most often cause delays in the procurement of goods in the Procurement Division of data obtained from some interviewed informants.

Based on the above description, it is known that the factors that cause the delay are mostly in the human category, with four factors, including the old clarification process, less labor, ineffective hours of work, and suppliers canceling orders unilaterally.

\section{CONCLUSION}

From the results of research and discussion conducted by researchers, it can be concluded as follows:

1. Likelihood of major factors in procurement is that the procurement system is still manual, not yet using the e-procurement system, in which the e-procurement system can create an efficient and effective system in the acquisition system by minimizing face-to-face with the supplier and minimizing the hard copy.

2. The second factor that delays in the goods is the lack of manpower, where the load burden is greater than the user compared to the number of retired workers.

Some of the recommendations that can be presented in this study are:

1. Creating an e-procurement procurement system, by conducting a comparative survey or comparative study with companies that have been using the e-procurement system as their procurement system

2. Make recruitment as a way of regenerating and adjusting loads to get more stuff.

\section{REFERENCES}

[1]. Doty, L A.1996.”Statistical Process Control. Second Edition”. New York : Industrial Press

[2]. Fernandez, R R, 1995, “Total Quality In Purchasing \& Supplier Management”, Terjemahan oleh Edi Nugroho, 1996, Penerbit Pustaka Binaman Pressindo, Jakarta

[3]. Bungin, B M. 2007. "Penelitian Kualitatif Edisi kedua", Penerbit Kencana Prenada Media Group, Jakarta.

[4]. Gaspersz V,1998. "Production Planning and Inventory Control”. PT. Sun. Jakarta

[5]. Graubitz, H.2006.’Ishikawa Diagram”.Jakarta

[6] Juran ,M J and Godefrey, A B. 1999. Juran’s Quality Handbook. Washington : McGraw-Hill 
[7]. Khang, C W and Paul, H K.2011. "Basic Statistical Tools for Improving Quality". New Jersey

[8]. Krisyantoro, R.2016. “Teknik Praktis Riset Komunikasi”.Jakarta

[9] Lexy J. M, 2007,’ Metode Penelitian Kualitatif”, Penerbit Remaja Rosdakarya, Bandung

[10]. Mnarwan, H dan Mustofa. 2014.’Perencanaan Produktifitas Kerja Dari Hasil Evaluasi Produktifitas Dengan Metode Fishbone Di Perusahaan Percetakan Kemasan PT X", Surabaya

[11]. Purba,HH.(2008). “Diagram Fishbone dan Ishikawa”.Jakarta

[12]. Yamit, Z. 2010. "Manajemen Kualitas Produk dan Jasa”. Ekonesia FE UII, Yogyakarta

[13]. Yuwono, M A.\& Riyadi, A S. 2016. “Proses Produksi dan Pengendalian Kualitas Produksi Cat Plastic Coating di PT.Propan Raya Icc". Tangerang 